\title{
Vostok (Antarctica) climate record time-scale deduced from the analysis of a borehole-temperature profile
}

\author{
A. N. Salamatin, \\ Department of Applied Malhemalics, Kazan State University, Kazan 420008, Russia \\ V. YA. LIPENKOV, \\ Arctic and Antarctic Research Institute, St. Petersburg 199397, Russia \\ K. V, BLiNoV \\ St. Petersburg Mining Institute, St. Petersburg 199026, Russia
}

\begin{abstract}
Several sets of temperature measurements were carried out in 197288 in the Vostok borcholes. They have provided the icc-shect temperature profile down to a depth of $2000 \mathrm{~m}$. The accuracy of the profile is sufficient to analyze pcrturbations induced by the surface-temperature variations over the last climatic cycle. The mathematical rrodel developed for the ice-temperature computation is applied to solve an inverse problem. The amplitudes and phase lags of the main harmonic components in the surface-temperature variations are reconstructed on the basis of fitting the calculated ice-temperature profile to the experimental one with the assumption that Milankovich's cycles $(100,41,23$ and 19 kyear $)$ are dominant in the climate oscillations. The paleotemperature record simulated with the inverse procedure is revealed to be insensitive to the model parameters varied within the range of their uncertainty. Minimal standard deviation between calculated and measured temperature profiles is found of the same order as the reproducibility of the temperature measurements $\left(0.005-0.01^{\circ} \mathrm{C}\right)$. Although the simulated temperaturetime curve obtained in this study does not contain short-term variations, all the main climate events predicted from the ice-core isotope analysis can be recognized. 'Thus, the age of the events can be verified independently of the ice-sheet dynamics dating. The resultant time-scale for the Vostok record appears to be in good agreement with the dating of climate events recorded in deep-sea sediments.
\end{abstract}

\section{INTRODUGTION}

Special studies and issues Dahl-Jensen and Johnsen, 1986; MacAycal and others, 1991; Palaeogeography, Palaeoclimatology, Palaeoecology, 1992) have been devoted to the inverse problems and methods aimed at reconstruction of past climatic changes from temperature measurements in deep boreholes. As a rule, this approach is cxtremely limited in application if no additional information about the form of an inferred paleotemperature time curve is taken into account. On the other hand, there is abundant evidence that Milankovich astronomic cycles probably were dominant in the Plcistoccne climatc oscillations (c.g. Jouzcl and others, 1987; Martinson and others, 1987).

Estimations based on theoretical approaches (Budd, 1969; Muravycy and Salamatin, 1990; and numerical predictions (Ritz, 1987) have shown that in the central parts of Antarctica the last 20-100 kyear periods of the Milankovich harmonic components of surface-temperature variations penetrate through the ice sheet down to its bottom, fading in amplitude not more than 5 times while passing $1-3 \mathrm{~km}$, respectively. Short-term temperature variations with periods less than 3-5 kyear with comparatively small amplitudes $\left(<1-2^{\circ} \mathrm{C}\right)$ are almost completely filtered out in the upper part of the ice sheet (above a depth of 200-300 $\mathrm{m}$ ) and cannot be observed in the deeper strata, while long-term variations with periods. exceeding 300 kyear do not induce a detectable waveshape signal in the vertical temperature profile because of insufficient thickness of the ice. The expected perturbations of the temperature field in the ice sheet, induced by the 20100 kyear long paleoclimate oscillations (Lorius and others, 1985; Jouzel and others, 1987), appear to be not less than $0.2-1.0^{\circ} \mathrm{C}$. Since the temperature measurements made in the $2000 \mathrm{~m}$ deep borehole at Vostok Station have an absolute error of $0.05^{\circ} \mathrm{C}$, they provide a certain registration of such a record.

From the above discussion, it seems reasonable for our purpose to imagine the surface-temperature oscillations as a sum of harmonics with the fixed Milankovich periods of $100,41,23$ and 19 kyear. Hence, only their amplitudes 
and phase lags are to be found by minimizing a standard deviation between the theoretical temperature distribution and the experimental temperature profile measured in the Vostok borehole. Then a comparison of the inferred paleotemperature-time curve with the ice-core isotope record would provide a possibility of verifying the age of the main climatic events independently of the ice-sheet dynamics dating. For the implementation of this plan, a sufficient mathematical model providing simulation of non-stationary temperature fields in the central part of the Antarctic ice sheet taking account of inhomogeneity and compressibility of the near-surface strata (Salamatin, 1991) has been developed by Salamatin and others (in press).

Thus, the dating approach introduced in this paper combincs the inverse procedure with an orbital tuning concept: a "metronomic record" destined for adjusting the isotope record time-scale is derived here from the borchole-temperature profile using the common assumption for orbital tuning about the linear climate response to variations in the Earth's orbital parameters. Although there is evidence of non-linear effects associated with icesheet waxing and waning (Imbrie and Imbrie, 1980) as well as with the amplifying role of greenhouse gases (Genthon and others, 1987), it has already becn shown that they mainly result in the shape of climatic events, while their timing does not change more than 3 kyear (Martinson and others, 1987). 'This is the basic belief of the authors which ensures the validity of further considerations. Indeed, the detailed temperature history older than 50-100 kyear does not noticeably affect the measured temperature depth profile and the borehole thermometry alone could not resolve the surfacetempcrature variations at greater times.

\section{EXPERIMENTAL DATA}

Systematic temperature measurements in the deep boreholes drilled at Vostok Station were started in 1972 in the dry hole which reached a depth of $950 \mathrm{~m}$. The results of geophysical studies that were carried out at the station in different boreholes before 1983, including temperature measurements made down to $2040 \mathrm{~m}$ in deep borehole 3G, were summarized by Vostretsov and others (1984). The accuracy of these data bclow $900 \mathrm{~m}$ does not exceed $0.1^{\circ} \mathrm{C}$ because they were obtained soon after the drilling was completed. Then temperature logging of borehole $3 \mathrm{G}$ was repeated several times during 1983-88. The last and most precise set of data was obtained in 1988 when the temperature profile was measured three times during the year: in April, July and September, with four-five readings each time at each depth. This has allowed us to estimate the experimental reproducibility of the measurements which has been found to be $0.005-0.01^{\circ} \mathrm{C}$, while absolute accuracy of the data is considered to be about $0.05^{\circ} \mathrm{C}$. The average values of the temperature together with its standard deviations at each examined depth level are presented in Table 1 . The accuracy achieved in this set of measurements is about one order greater than that of the joint results from 1972-82 (Vostretsov and others, 1984), which were used earlier by Ritz (1989) for
Table 1. Borehole temperature (experimental data)

$\begin{array}{cccccc}\text { Depth } & \begin{array}{c}\text { Mean } \\ \text { temperature }\end{array} & \begin{array}{c}\text { Standard } \\ \text { deviation }\end{array} & \text { Depth } & \begin{array}{c}\text { Mean } \\ \text { temperature deviation }\end{array} & \begin{array}{c}\text { Standard } \\ \text { demention }\end{array} \\ \mathrm{m} & { }^{\circ} \mathrm{C} & { }^{\circ} \mathrm{C} & \mathrm{m} & { }^{\circ} \mathrm{C} & { }^{\circ} \mathrm{C}\end{array}$

\begin{tabular}{rrrrrr}
100 & -56.630 & 0.008 & 1020 & -48.939 & 0.004 \\
120 & -56.509 & 0.012 & 1040 & -48.736 & 0.008 \\
140 & -56.359 & 0.021 & 1060 & -48.525 & 0.008 \\
160 & -56.208 & 0.007 & 1080 & -48.324 & 0.004 \\
180 & -56.080 & 0.012 & 1100 & -48.110 & 0.006 \\
200 & -55.939 & 0.012 & 1120 & -47.901 & 0.011 \\
220 & 55.802 & 0.003 & 1140 & -47.688 & 0.007 \\
240 & -55.654 & 0.007 & 1160 & -47.475 & 0.005 \\
260 & -55.507 & 0.007 & 1180 & -47.253 & 0.005 \\
280 & 55.357 & 0.004 & 1200 & -47.039 & 0.007 \\
300 & -55.207 & 0.006 & 1220 & -46.818 & 0.003 \\
320 & -55.052 & 0.007 & 1240 & -46.591 & 0.005 \\
340 & -54.901 & 0.005 & 1260 & -46.366 & 0.004 \\
360 & -54.743 & 0.007 & 1280 & 46.134 & 0.009 \\
380 & -54.589 & 0.006 & 1300 & -45.908 & 0.006 \\
400 & -54.432 & 0.005 & 1320 & -45.676 & 0.005 \\
420 & -54.272 & 0.005 & 1340 & 45.449 & 0.009 \\
440 & -54.114 & 0.003 & 1360 & -45.215 & 0.006 \\
460 & -53.955 & 0.004 & 1380 & -44.978 & 0.004 \\
480 & -53.795 & 0.002 & 1400 & -44.735 & 0.005 \\
500 & -53.634 & 0.003 & 1420 & -44.491 & 0.009 \\
520 & -53.471 & 0.003 & 1440 & 44.251 & 0.001 \\
540 & -53.311 & 0.005 & 1460 & -44.004 & 0.006 \\
560 & -53.143 & 0.002 & 1480 & -43.754 & 0.010 \\
580 & -52.977 & 0.005 & 1500 & -43.507 & 0.014 \\
600 & -52.811 & 0.004 & 1520 & -43.271 & 0.007 \\
620 & -52.642 & 0.005 & 1540 & -43.017 & 0.003 \\
640 & -52.472 & 0.005 & 1560 & -42.735 & 0.005 \\
660 & -52.301 & 0.001 & 1580 & -42.493 & 0.004 \\
680 & 52.127 & 0.004 & 1600 & -42.213 & 0.003 \\
700 & -51.953 & 0.002 & 1620 & -41.943 & 0.004 \\
720 & -51.774 & 0.004 & 1640 & -41.669 & 0.010 \\
740 & -51.598 & 0.004 & 1660 & -41.412 & 0.005 \\
760 & -51.421 & 0.005 & 1680 & -41.131 & 0.001 \\
780 & -51.239 & 0.004 & 1700 & -40.857 & 0.002 \\
800 & -51.054 & 0.005 & 1720 & -40.581 & 0.004 \\
820 & -50.871 & 0.007 & 1740 & -40.295 & 0.006 \\
840 & 50.687 & 0.006 & 1760 & -40.008 & 0.005 \\
860 & -50.498 & 0.006 & 1780 & -39.714 & 0.007 \\
880 & -50.312 & 0.006 & 1800 & -39.439 & 0.008 \\
900 & -50.121 & 0.006 & 1820 & -39.134 & 0.007 \\
920 & -49.931 & 0.006 & 1840 & -38.858 & 0.003 \\
940 & 49.734 & 0.005 & 1860 & 38.552 & 0.014 \\
960 & -49.537 & 0.007 & 1880 & -38.257 & 0.007 \\
\hline & -49.340 & 0.007 & 1900 & -37.956 & 0.006 \\
& -49.140 & 0.005 & 1920 & -37.660 & 0.022 \\
& & & & & \\
\hline
\end{tabular}

verification of their agreement with the ice-core isotope analysis. Let us assume hercafter the temperature $T_{\mathrm{h}}{ }^{0}=-57.4^{\circ} \mathrm{C}$ to be a reference origin point close to 
the mean contemporary temperature observed on the ice-sheet surface at Vostok Station. The present-day accumulation rate $w_{\mathrm{h}}{ }^{0}$ expressed in ice equivalent is supposed to be within the range of $2.0-2.7 \mathrm{~cm} \mathrm{ycar}^{-1}$ (Lorius and others, 1985; Jouzel and others, 1993) and the glacier thickness $h_{0}$ is estimated as $3725 \mathrm{~m}$, according to direct measurements by Kapitsa and Sorohtin (1965) and temperature simulations by Barkov and others (1989). The ice-sediment density ( $\rho$ ) variation versus depth (h) caused by the firn and ice densification (Salamatin and others, 1985) can be approximated by the following relation:

$$
\rho=\rho_{0}\left(1-c_{1} \mathrm{e}^{-\gamma h}\right)
$$

where $\rho_{0}$ is the density of pure ice $\left(0.92 \mathrm{Mg} \mathrm{m}^{-3}\right), \gamma=$ $0.021 \mathrm{~m}^{1}, \mathrm{c}_{\mathrm{h}}=0.69$.

The corresponding ice-sheet thickness in ice equivalent $h_{0}^{\prime}$ is $3692 \mathrm{~m}$ and the fusion temperature $T_{\mathrm{f}}$ at the bottom (pressure-melting point) is about $-2.4^{\circ} \mathrm{C}$. Additionally, the researches by Shumskii (1969) and Vostretsov and olhers (1984) have shown that the thermal conductivity coefficient of firn and ice with air inclusions differs from the thermal conductivity $\lambda$ of pure ice. Their ratio $\Lambda$ depends on the relative density $\rho^{*}=\rho / \rho_{0}$ following Maxwell's formula (Shumskii, 1969; Muravyev and Salamatin, 1990):

$$
\Lambda=2 \rho^{*} /\left(3-\rho^{*}\right) \text {. }
$$

\section{MODEL DESCRIPTION}

The following studies preceded the final formulation of the mathematical model for temperature simulation in the ice sheet at Vostok. First, the general equations describing the glacier flow along a fixed flowline and taking account of the inhomogeneity and compressibility of near-surface ice strata were derived by Salamatin (1991). Then, the latter were investigated to estimate the possible influence of their different terms and factors on the temperature predictions (Salamatin and others, in press. In particular, the analysis of these equations shows that the convective-heat transfer in the vertical direction (provided that the profile of the density $\rho$ is invariant in time) is governed by the effective rate of the ice-mass transfer, which can be expressed in the dimensionless form:

$$
\begin{aligned}
W^{*}= & -W_{\mathrm{h}}+\left(1-Z^{*}\right)\left[W_{\mathrm{h}}-W_{0}+\sigma\left(W_{\mathrm{h}}-W_{0}-\frac{\partial \Delta}{\partial t}\right)\right. \\
& \left.\cdot \frac{1-\left(1-Z^{*}\right)^{\alpha+1}}{\alpha+1}\right], \quad Z^{*}=\frac{Z}{\Delta}
\end{aligned}
$$

Here, $W_{\mathrm{l}}$ and $W_{0}$ are the relative rates of the surface accumulation and the basal ice melting normalized by $w_{\mathrm{h}}{ }^{0} ; Z$ and $\Delta$ are the distance from the bed and the icesheet thickness in ice equivalent related to $h_{0}^{\prime}$, respectively; $\sigma$ is the imitation switch parameter, i.e. the ratio between the ice-flow rate which corresponds to the glacier body plastic deformation and the total flow rate which includes ice sliding at the bottom: $0 \leq \sigma \leq 1(\sigma=0$, when ice sliding takes place in the basal layer and the shear strains in the glacier body are zero; $\sigma=1$, when there is no ice sliding at the bed); $\alpha$ is the creep index in Glen's rhcological law modified for non-isothermal conditions in accordance with the theory of Lliboutry (1979); $t=\tau w_{\mathrm{h}}{ }^{0} / h_{0}^{\prime}$ is the dimensionless form of the time $\tau$.

To make it clear, it must be mentioned that Equation (3) was deduced on the basis of conventional assumptions of the thin-layer approximation theory. However, $W^{*}$ is not exactly the vertical vclocity of the ice. Actually, this value describes the ice movement in the normalized $Z^{*}$ - coordinate systcm and, thus, takes into account temporal and longitudinal variations of icesheet thickness.

The following assumptions were also discussed and justified for the Vostok region by Salamatin and others (in press):

(a) The strain heating in the near-bottom ice layer in the vicinity of Vostok Station remains practically invariant in time. Its influence on the temperature distribution in the upper $2000 \mathrm{~m}$ of ice strata can be taken into account by appropriate correction of the geothermal flux $q_{0}$ at the ice-rock interface.

(b) The longitudinal convective-heat transfer does not render noticcable influence on the formation of temperature perturbations in the icc sheet linked with changes in climatic conditions, and the corresponding effect on the stationary component of the temperature field is negligibly small in comparison with the existent uncertainty of the model parameters.

(c) The simplified model (Ritz, 1989 )

$$
\partial \Delta / \partial t=W_{\mathrm{h}}-\left\langle W_{\mathrm{h}}\right\rangle,
$$

where $\langle\cdot\rangle$ denotcs long-history time averaging, can be accepted to estimate possible maximal icethickness oscillations in the vicinity of Vostok Station and their effect on the temperature profile in the ice sheet.

(d) If the ice sheet is assumed to be composed of pure ice throughout its thickness, one must write the special boundary conditions on its surface not to violate the heat balance and temperature distribution below the upper heterogeneous layer:

$$
\begin{aligned}
-\left.\frac{\partial \theta}{\partial Z^{*}}\right|_{Z^{*}=1} & \\
& =\left[\int_{0}^{1}\left(\frac{1}{\rho^{*} \Lambda}-1\right) \mathrm{d} Z^{*}\right]^{-1}\left(\left.\theta\right|_{Z^{*}=1}-\theta_{11}\right)
\end{aligned}
$$

where $\theta$ and $\theta_{\mathrm{h}}$ are the dimensionless temperatures in the ice sheet and on its surface, respectively, $\theta=$ $\left(T-T_{\mathrm{h}}^{0}\right) /\left(T_{\mathrm{f}}-T_{\mathrm{h}}^{0}\right) ; T$ is the temperature in ${ }^{\circ} \mathrm{C}$.

The computational experiments performed by Barkov and others (1989) and by Ritz (1989) have made it evident that the basal ice in the vicinity of Vostok Station is at its melting point. Hence, using Equations (1) and (2) to evaluate the integral in relation (5), we finally arrived at the following quasi-one-dimensional heat-transfer model (Salamatin and others, in press): 


$$
\begin{aligned}
c^{*} \operatorname{Pe} \Delta^{2}\left(\frac{\partial \theta}{\partial t}+\frac{W^{*}}{\Delta} \frac{\partial \theta}{\partial Z^{*}}\right)= & \frac{\partial}{\partial Z^{*}}\left(\lambda^{*} \frac{\partial \theta}{\partial Z^{*}}\right) \\
& -t_{0}<t<0, \quad 0<Z^{*}<1 ;
\end{aligned}
$$$$
\text { (a) } \theta_{\mid Z^{*}=0}=1 ; \quad(b)-(\kappa / \Delta)\left(\partial \theta / \partial Z^{*}\right)_{\mid Z^{*}=1}=\theta_{\mid Z^{*}=1}-\theta_{\mathrm{h}} \text {. }
$$

Hcre, $t_{0}$ is the wholc time interval in the past taking into consideration $\left(t_{0}>0\right) ; c^{*}$ and $\lambda^{*}$ are the relative specific heat and thermal conductivity coefficicnts of ice normalized by their corresponding values $c_{0}$ and $\lambda_{0}$ at a temperature of $-30^{\circ} \mathrm{C} ; \mathrm{Pe}=c_{0} \rho_{0} w_{11}{ }^{0} h_{0}^{\prime} / \lambda_{0}$ is the Peclet number;

$$
\kappa=\left[c_{\mathrm{h}}-\left(\frac{3}{2}\right) \ln \left(1-c_{\mathrm{h}}\right)\right] /\left(\gamma h_{0}^{\prime}\right) \approx 0.032 .
$$

In accordance with Budd (1969) and Vostretsov and others (1984):

$$
\begin{array}{cc}
c_{0}=1.88 \mathrm{~kJ} \mathrm{~kg}^{-1}{ }^{\circ} \mathrm{C}^{-1} ; & \lambda_{0}=2.55 \mathrm{~W} \mathrm{~m}^{-1}{ }^{\circ} \mathrm{C}^{-1} ; \\
c^{*}=1+\alpha^{*}{ }_{\mathrm{c}}(\theta-0.5) ; & \lambda=1-\alpha^{*}{ }_{\lambda}(\theta-0.5) ; \\
\alpha^{*}{ }_{\mathrm{c}} \approx 0.23 ; & \alpha^{*}{ }_{\lambda} \approx 0.24 .
\end{array}
$$

The relative ice-melting rate at the bed in Equation (3) is determined by equation:

$$
W_{0}=\left[K_{\mathrm{q}}+\lambda^{*}\left(\partial \theta / \partial Z^{*}\right)_{Z^{*}-0} / \Delta\right] / K_{\mathrm{f}} .
$$

Criteria $K_{\mathrm{q}}$ (dimcnsionless geothermal flux) and $K_{\mathrm{f}}$ (phase-change number) are given by formulas:

$K_{\mathrm{q}}=q_{0} h_{0}^{\prime}\left[\lambda_{0}\left(T_{\mathrm{f}}-T_{\mathrm{h}_{\mathrm{l}}}{ }^{0}\right)\right], K_{\mathrm{f}}=\rho_{0} w_{\mathrm{h}_{\mathrm{l}}}{ }^{0} h_{0}^{\prime} L /\left[\lambda_{0}\left(T_{\mathrm{f}}-T_{\mathrm{h}}{ }^{0}\right)\right]$

where $L=333 \mathrm{~kJ} \mathrm{~kg}^{1}$ is the latent heat of ice fusion.

An appropriate relation between the climatic characteristics $W_{l_{1}}$ and $\theta_{h}$ is to be formulated to complete the mathematical model for the simulation of non-stationary temperature processes in the ice sheet. 'The findings of Robin (1977) give us the basis for expressing the accumulation rate via the water-vapor pressure in the air. Using the cmpirical Magnus's formula and following Jouzel and others (1987) and Ric\% (1989), for relatively small surfacc-temperature variations $\theta_{\mathrm{h}}$, onc can obtain:

$$
W_{\mathrm{h}}=\exp \left[\beta^{*}{ }_{\mathrm{w}}\left(\theta_{\mathrm{h}}-\theta_{\mathrm{h} \mid t=0}\right)\right]
$$

with $\beta^{*}{ }_{\mathrm{w}} \approx 4.12 \times 10^{3}\left(T_{\mathrm{f}}-T_{\mathrm{h}}{ }^{0}\right) /\left(273.15+0.67 T_{\mathrm{h}_{\mathrm{h}}}{ }^{0}\right)^{2} \approx$ 4.1 at Vostok.

Finally, substitution of the latter expression into Fquation (4) yields the model for the ice-thickness calculation (Salamatin and others, in press):

$$
\partial \Delta / \partial t=\beta^{*}{ }_{\mathrm{w}}\left(\theta_{\mathrm{h}}-\left\langle\theta_{\mathrm{h}}\right\rangle\right) \exp \left[\beta^{*}{ }_{\mathrm{w}}\left(\left\langle\theta_{\mathrm{h}}\right\rangle-\theta_{\mathrm{h} \mid t=0}\right)\right] .
$$

\section{INVERSE PROCEDURE}

As has already been mentioned, the high-frequency paleotemperature records (of periods less than 3-5 kycar) are filtered out and do not penetrate into the
Antarctic ice sheet decper than $200 \mathrm{~m}$, because of the low thermal conducivity of the upper firn-ice sediments. On the other hand, long-period temperature oscillations on the ice-sheet surface (with periods larger than 300 kyear) do not induce noticeable temperature fluctuations in the ice because of its limited thickness. At the same time, the temperature profile from the deep borehole drilled at Vostok can contain information about temperature variations with Milankovich astronomic periods $\left(\tau_{1}=\right.$ $100, \tau_{2}=41, \tau_{3}=23, \tau_{4}=19$ kyear) over the last climatic cyclc. These oscillations prevail in the known paleoclimatic records (e.g. Jouzel and others, 1987; Martinson and others, 1987). Hence, the inferred component of climate changes on the Antarctic ice-sheet surface in the vicinity of Vostok Station can be written as a sum of harmonics:

$$
\begin{aligned}
\theta_{\mathrm{h}}(t)= & \left\langle\theta_{\mathrm{h}}\right\rangle+\sum_{i=1}^{4}\left\{A_{i} \cos \left[\Omega_{i}\left(t+t_{0}\right)\right]\right. \\
& \left.+B_{i} \sin \left[\Omega_{i}\left(t+t_{0}\right)\right]\right\}
\end{aligned}
$$

where $\Omega_{i}=2 \pi h_{0}^{\prime} /\left(\tau_{i} w_{\mathrm{h}}^{0}\right)$. Obviously, this sum does not take into account individual secondary details and, therefore, may differ from the real temperature variations in the magnitude of amplitudes and in the relative height of peaks. The values $\Omega_{i}$ are fixed and there are eight unknown parameters: $A_{i}$ and $B_{i}(i=1, \ldots, 4)$ in Equation (11).

Let us denote a sufficiently large interval of time in the past: $t_{0} \gg t_{1}=\tau_{1} w_{\mathrm{h}}{ }^{0} / h^{\prime}$ and introduce an initial condition in the boundary valuc in problem (6) in the following form:

$$
\theta_{\mid t=-t_{i)}}=\theta_{0}(Z)
$$

where $\theta_{0}$ is the steady-state temperature distribution in the ice sheet with the surface temperature $\theta_{\mathrm{h}} \equiv\left\langle\theta_{\mathrm{h}}\right\rangle$.

'l'hen, let $\theta_{\mathrm{ex}}$ be the dimensionless temperature profile measured in the decp borehole at Vostok Station at points $Z=Z_{\mathrm{k}}, k=1, \ldots, N$. The mean square-deviation function can be defined on the basis of the mathematical model (3), (6) (12) and the experimental temperature profilc:

$$
\begin{gathered}
S\left(A_{1}, \ldots, B_{1}, \ldots ;\left\langle\theta_{\mathrm{h}}\right\rangle, \operatorname{Pe}, K_{\mathrm{q}}, K_{\mathrm{f}}, \sigma, \alpha\right) \\
=\left\{\sum_{k=1}^{N}\left[\theta_{\mathrm{ex}}\left(Z_{\mathrm{k}}\right)-\theta\left(Z_{\mathrm{k}}, t=0\right)\right]^{2} / N\right\}^{\frac{1}{2}} .
\end{gathered}
$$

Thus, the inverse procedure of inferring the climatic parameters, $A_{i}, B_{i}(i=1 \ldots, 4)$ comes to the problem of minimizing the $S$-function at fixed plausible values of $\left\langle\theta_{\mathrm{h}}\right\rangle, \mathrm{Pe}, K_{\mathrm{q}}, K_{\mathrm{f}}, \sigma, \alpha$.

The solution of the boundary-value problem (3), (6) (12) is computed, using the finitc-difference method in accordance with the implicit time-scheme algorithm. The space step for the $Z^{*}$-coordinate is $1 / 40$. The time-interval length $t_{0}$ is taken cqual to $3 t_{1}$ and the time step is $t_{0} / 150$. The choice is based on the preliminary test runs of the model. 'This cnsures that the accuracy of the calculations is not worse than the reproducibility of the ficld measurements.

The minimization of target function (13) is performed 
on the basis of the Newton method and the gradient method of stcepest descent. A special interactive computer sistem for IBM-PC has been developed to perform the inverse procedure and the comparison of the reconstructed paleotemperature-time curve with clim-atic records from the Vostok ice core.

\section{PALEOGLIMATIC RECONSTRUCTION}

All computations on paleotemperature reconstructions considered in this section have been performed using the data obtained in 1988 (sec Table 1 ). The total number of various sets of numerical experiments at different plausible values of the model parameters: $\left\langle\theta_{\mathrm{h}}\right\rangle, \mathrm{Pe}, K_{\mathrm{q}}$, $K_{\mathrm{f}}, \sigma$ and $\alpha$ has exceeded 100 .

The starting tests have revealed the fact that the possible small variations of the mean surface temperature within the range $-0.09<\left\langle\theta_{\mathrm{h}}\right\rangle<-0.05$ (i.e. $-62.35<$ $\left.\left\langle T_{\mathrm{h}}\right\rangle<-60.15^{\circ} \mathrm{C}\right\rangle$ do not influence the accessible minimal level of deviation (13) and the inferred climatic signal. Therefore, this parameter should be fixed. According to the Vostok isotope record (Jouzel and others, 1987), the $\left\langle\theta_{\mathrm{h}}\right\rangle$ value is taken hereafter equal to -0.07 (i.e. $\left\langle T_{\mathrm{h}}\right\rangle=$ $-61.25(\mathrm{C})$.

Following Lliboutry (1979) and Ritz (1989), the nonisothermal conditions of the Antarctic icesheet shear deformation in the basal layer can be modeled assuming $\alpha \approx 10$. With this assumption, the two limiting situations are considered: (1) $\sigma=1$, when the ice-sliding velocity on the bedrock is zcro, and (2) $\sigma=0$ (i.e. $\alpha \rightarrow \infty$ ) with no shear strain in the bottom ice. The minimum of the standard deviation $S$ between the computed and observed temperature profiles is determined for different values of the geothermal flux (including strain heating) and the present-day accumulation rate within the intervals: $2.0<w_{\mathrm{h}}{ }^{0}<2.7 \mathrm{~cm} \mathrm{year}^{1}$ and $0.05<q_{0}<0.06 \mathrm{Wm}^{2}$. In both cases, the best fits are found at $q_{0} \approx 0.053 \mathrm{~W} \mathrm{~m}^{2}$ and at definite values of $w_{1}{ }^{0}$ :

(1) for $\sigma=1$

$w_{1}{ }^{0}=2.6 \mathrm{~cm}$ year ${ }^{1}\left(\mathrm{Pe}=2.06, K_{\mathrm{q}_{\mathrm{i}}}=1.4, K_{\mathrm{f}}=6.6\right)$

$A_{1}=0.0835, A_{2}=-0.0505, A_{3}=-0.0677, A_{4}=0.0082$;

$B_{1}=0.0358, B_{2}=0.0546, \quad B_{3}=-0.0239, B_{4}=0.0241 ;$

$S=1.67 \times 10^{-4}\left(\sim 0.0092^{\circ} \mathrm{C}\right)$;

(2) for $\sigma=0$

$w_{1}^{0}=2.2 \mathrm{~cm} \mathrm{ycar}^{1}\left(\mathrm{Pc}=1.7, K_{\mathrm{q}}=1.4, K_{\mathrm{f}}=5.6\right)$

$A_{1}=0.0880, A_{2}=-0.0566, A_{3}=-0.0638, A_{4}=0.0142$

$B_{1}=0.0614, B_{2}=0.0577, \quad B_{3}=-0.0345, B_{4}=0.0366$; $S=1.71 \times 10^{-4}\left(\sim 0.0094^{\circ} \mathrm{C}\right)$.

The corresponding temperature-time curves are presented in Figurc la and will be referred to hereafter as I and II, respectively. The discrepancies between the computed and observed temperature profiles are of the same order as a reproducibility of the experimental data (see Fig. 1b).

The minimization procedure is tested at various initial values of amplitudes $A_{i}, B_{i}, i=1, \ldots, 4$. In a single case, for the condition with $\sigma=1$ another minimum with standard deviation close to the best fit I has been found at $w_{\mathrm{h}}{ }^{0}=2.4 \mathrm{~cm}$ year ${ }^{1}$. The corresponding paleotemper-
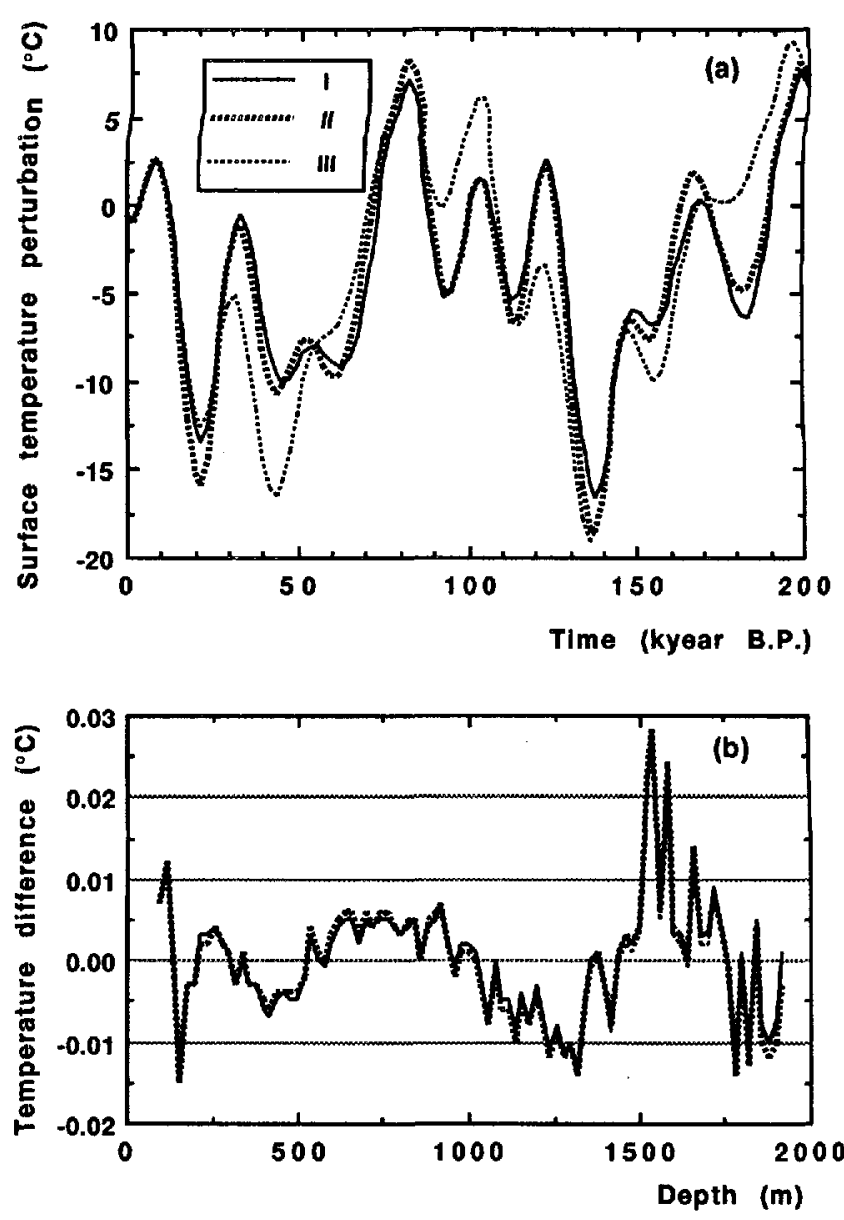

Fig. 1. a. Surface-temperature variations zersus lime inferred by inverse procedure from a borehole-lemperature profile under the different assumptions: (1) when there is no sliding al the ice rock interface $(\sigma=1)$ : (II) basalsliding condition $(\sigma=0)$; (III) particular variant for a non-sliding condition $(\sigma=1)$. b. Mismatch betzeen the computed and observed borehole-temperature profiles referred to variants $I, I I$ and $I I I$.

ature reconstruction (see curve III in Figure la) is very different in shape from the two main variants I and II among all tested, while no significant change in climatic cvent timing is observed. The shift of age for rcconstructed temperature oscillations always remains less than 3 kyear.

Additional computational experiments have been performed to estimate the sensitivity of the deduced paleotemperature curve to the different boundary conditions and properties of ice. For instance, if the water. produced by melting at the bottom of the ice sheet does not penetrate into the underlying rock and a subglacial lake is formed, the bottom melting rate $W_{0}$ tends to zero which can formally be taken into account by assuming the dimensionless number $K_{f}$ in Equation (8) equal to infinity. In this case, the best fit has been determined at $w_{\mathrm{h}}{ }^{0}=2.3 \mathrm{~cm}_{\text {year }}{ }^{1}(\sigma=0)$. The different thermophysical propertics of icc: $c_{0}=1.9 \mathrm{~kJ} \mathrm{~kg}^{-10} \mathrm{C}^{-1}, \lambda_{0}=2.66 \mathrm{~W}$ ${ }^{1} \mathrm{C}^{1} ; a_{\mathrm{c}}^{*}=0.193 ; a_{\lambda}^{*}=0.308$ used by Ritz (1989) have also been considered. The optimal value of accumulation rate $w_{\mathrm{h}}{ }^{0}$ is $2.25 \mathrm{~cm} \mathrm{year}^{-1}$ at $\sigma=1$. In the two above cases $q_{0}$ is found to be equal to $0.053 \mathrm{~W} \mathrm{~m}^{2}$ and $S \approx 1.7 \times 10^{-4}\left(\sim 0.0094^{\circ} \mathrm{C}\right)$. It is also remarkable that the predicted best-fit accumulation rate falls within the above- 
mentioned range of experimental data for the recent precipitation at Vostok.

All the computational tests, as well as numerical experiments with various values of $\beta^{*}$ w in Equations (9) and $(10)$, fully confirm the conclusion that in spite of the fact that computed paleotemperature oscillations can significantly differ from one variant to another by the amplitudes of their harmonic components, nevertheless, the principal events (peaks and (roughs) in the simulated curve are always reproducible, easily recognizable and their ages are definitely predictablc. The palcotemper-ature signal deduced from Equation (11) should be regarded only as a dominant "metronomic" part of the past surface-temperature variations. It cannot quantit-atively give the real (detailed) surface-temperature oscil-lations.

\section{VOSTOK GLIMATE-RECORD DATING}

Isotope, atmospheric gas and aerosol analysis of the Vostok ice core (Lorius and others, 1985; Jouzcl and others, 1987; Petit and others, 1990; Jouzel and others, 1993) has provided information of fundamental importance, since the obtained time series quantitatively characterize the past climate changes at high resolution. One of the principal problems of interpretation of these data is the determination of the ice-core chronostrat-igraphy. Traditionally, the age of ice is computed on the basis of the ice-flow modeling (Lorius and others, 1985; Ritz, 1992), although this approach lacks the necessary information about the upstream surface conditions: accumulation rate, ice thickness, temperature gradient, etc. On the other hand, the paleotemperature reconstruction inferred from the deep borchole tcmpcrature mcasurements immcdiately refers climatic events to a certain place on the time-scale. As has been emphasized above, the age of the peaks in such a computed temperature-time curve depends only slightly on the model parameters. In this section, we consider these peaks as fixed points with known age (similar to stratigraphic markers) for correcting the isotope temperature-record preliminary time-scale.

First, we applicd a mean square spline approximation to the original isocope temperature record from Jouzel and others (1987) which is shown in Figure 2a by dots. The smoothing aimed to conserve in the experimental record only the main temperature oscillations also reflected in the computed curve see thick line in Figure 2b), thus all major climatic events (temperature maxima and minima) could be easily identified in both of them. Our smoothed curve is shown in Figure 2 a together with a more detailed one obtained by Jouzel and others (1987) by spline smoothing of the 100 year equally spaced isotope values: thick and thin lines, respectively.

Secondly, we forced istretched linearly between adjacent peaks and troughs) the smoothed isotope record versus depth to correlate with the temperature-time curve deduced from the borehole-temperature profile. The normalized surface-temperature oscillations (refer to variant $I$ in Figure la) and the smoothed isotope-temperature record are plotted against time in Figure $2 b$ by thick and thin lines, respectively. The correlation cocfficient $r$ between the two curves is 0.72 , although amplitudes of some of their oscillations are significantly different. A

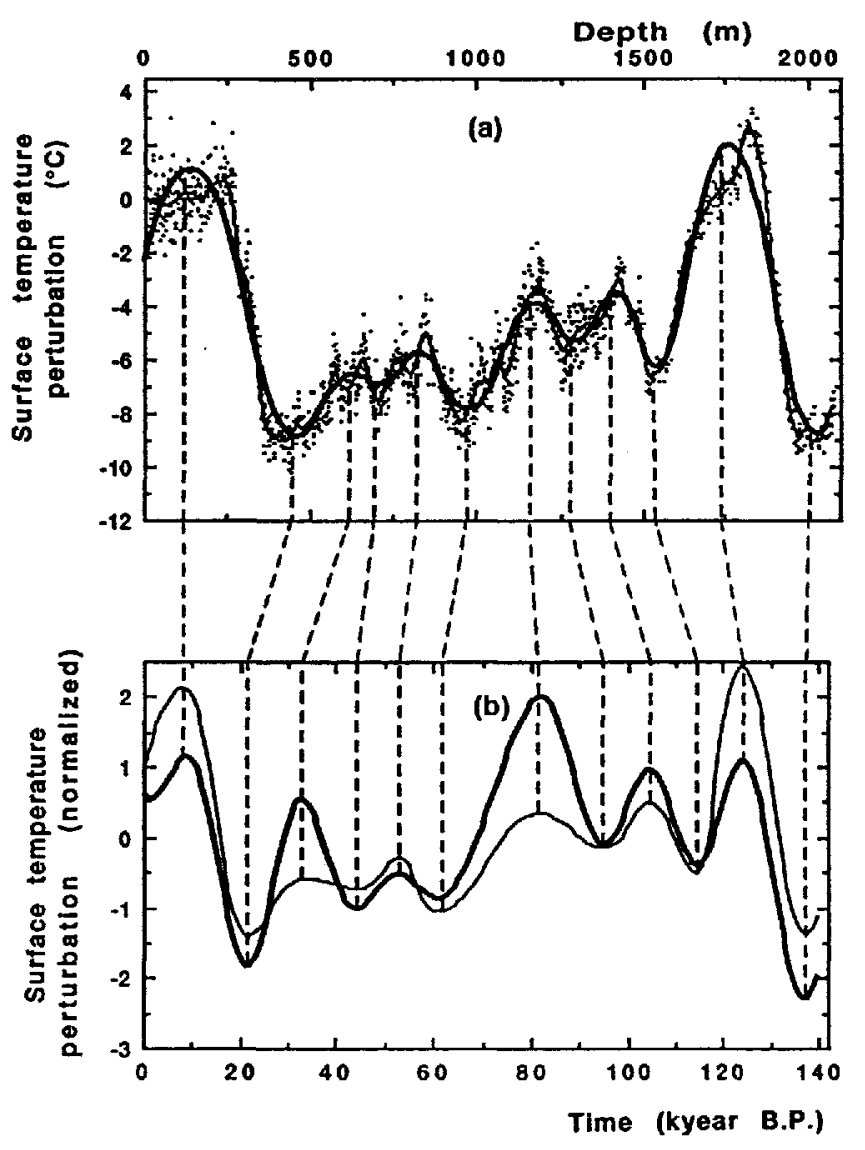

Fig. 2. The dating of the Vostok climate record on the basis of its fitting to the temperalure-time curve derived from the analysis of the borehole-temperature profile. a. Isotope-temperature variations against depth in the Vostoh ice core. The dots correspond to individual values; the thin line is a smoothed curve (from fouzel and others, 1987). The thick (bold) line is a cubic-spline approximation of the isotope data adjusted to facilitate the comparison between the experimental and compuled paleolemperature curves. The dashed vertical lines connect the identical peaks and lroughs in the experimental and computed curves. $b$. Vostok normalized surface temperature-time curves. The thin line corresponds to the spline approximation of the Vostok isotope record which was correlated to the computed paleotemperature curve shown by the thick line (refers to varianl I in Figure 1a).

similar value $r=0.70$ is obtained for the best-fit curve II and $r=0.54$ for solution III. It is relevant to emphasize here in the discussion that we did not expect better coincidence in amplitude size, because the in-formation about surfacc-temperature variations in the distant past (more than 70100 kyear ago) had already been lost in the temperature profile in the Antarctic ice sheet. Thus, the Milankovich astronomic metronome is tuned in accordance with the comparatively recent climate history.

Obviously, the corresponding time-scales deduced for Vostok through the identified peak events are the compounds of straight lines. It should be emphasized here that irrespective of the degree of correlation betwecn the inferred temperature time variations and the isotopetemperature record, all the chronologies co-incide with each other within a range of 2-3 kyear. 
The resulting Vostok climate record time-scale derived from the best-fit paleoreconstruction $\mathbf{I}$ is presented in Figure 3a. The pcak age discrepancies in the different computational experiments are shown by error bars. The two other Vostok ice-core chronologies based on the iceflow modeling: (b) "old dating" (Lorius and others, 1985) and (c) "extended glaciological time-scale" (EGT) from Jouzel and others (1993) are also shown in Figure 3.

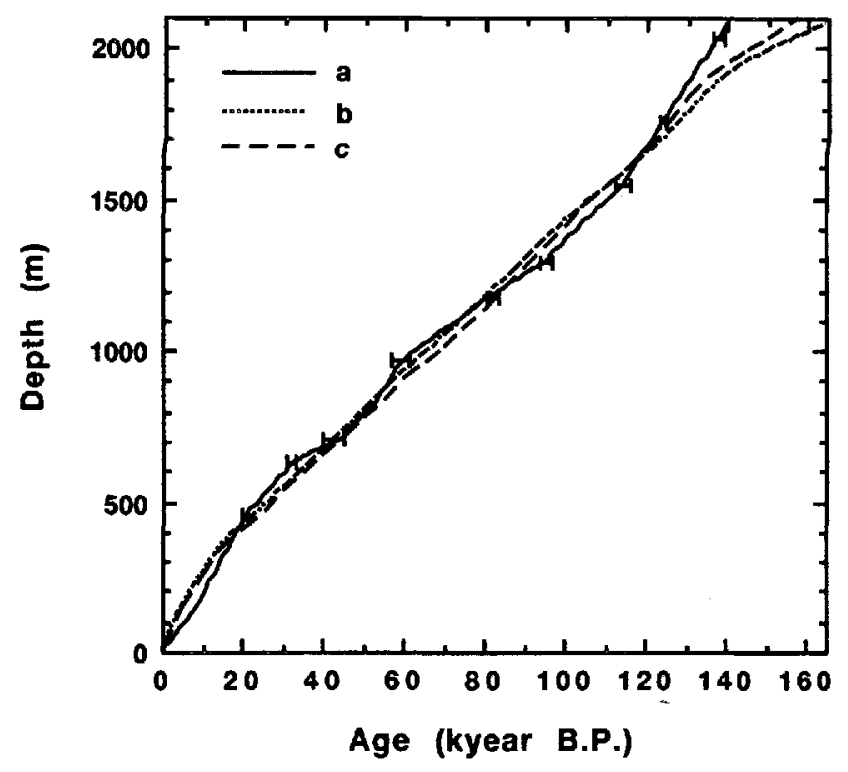

Fig. 3. Comparison of three Vostok ice-core chronologies: a. Time-scale deduced from the analysis of the boreholetemperature profile (the error bars show the age ranges in different computational variants); $b$. Depth-age relationship derived by Lorius and others (1985) on the basis of ice-flow modeling; c. Vostok ice core "extended glaciological time-scale" from fouzel and others (1993).

Apart from the quality of the assumptions taken as a basis for our dating and unccrtainties linked with model parameters (2 3 kyear), there is another source of error associated with success of positioning in the isotopetcmperature record the temperature maxima and minima accepted as fixed points in the spline-smoothing proced-ure. To estimate the limits of this error, we cxamine the discrepancy between different time-scales in the upper part of the Vostok ice core, where the Holocene mid-peak positioning in the isotope record is quite uncertain and the datings derived from ice-flow modeling are most reliable. The difference between our time-scale and EGT for this part of the ice core does not exceed 3.5 kyear and can be considered hereafter as a limit of the peak position-ing error. The deviation of the depth-age relationship developed in this work from the EGT curve remains within the range of \pm 5 kyear (i.e. within the gencral accuracy limit of dating) for most parts of the Vostok ice core (see Fig. 3). For example, our approach gives an age of 113.9 kyear for a depth of $1534 \mathrm{~m}$ instead of $110 \pm 3$ kyear which was accepted by most investigators (Jouzel and others, 1993) and was used as a tuning point for the EGT chronology. The noticeable discrepancy can be observed for the large depths only, where the accumulation rate upstream of
Vostok is determinant. This disagreement can be eliminated if one assumes an increase in the current precipitation rate in the ice-divide direction ( $\mathrm{Ritz}$, 1992). The latter seems to be realistic and has been partially confirmed by the information extracted from the ${ }^{10}$ Be data obtained for the Vostok ice core Jouzel and others, 1993). A preliminary comparison of the reconstructed metronomic palcotemperature signal (see Fig. la) with the extended isotope-temperature record from Vostok down to a depth of $2546 \mathrm{~m}$ (Jouzel and others, 1993) also shows a good agreement between the two chronologies. According to our dating, the $2500 \mathrm{~m}$ depth ice is about 11 kycar younger than what is predicted by the EGT.

The new dating of the ice core puts the Vostok temperature rccord (see Fig. 2b, thin line) practically in phase (with an accuracy \pm 2 kyear) with the global icevolume changes represented by the marine $\delta^{18} \mathrm{O}$ SPECMAP (Martinson and others, 1987). Petit and others (1990) reached the same conclusion, using atmospheric dust as a stratigraphic marker to compare Vostok timing with other paleoclimate records.

\section{CONGLUSION}

The inverse procedure has been developed to reconstruct paleotcmperature oscillations on the Antarctic ice-sheet surface from the temperature profile measured in the deep borehole at Vostok Station. The liming of the main events of the inferred climate changes appcars to be insensitive to the possible variations of the model parameters within the range of their uncertainty. Thus, the correlation between the reconstructed temperature-time curve and the smoothed temperature record derived from the ice-core isotopc analysis yields the age-depth relationship for Vostok paleorecords. Although our approach cannot present the detailed picture of paleotemperature variations, it provides another way of dating climate records. Actually, the results suggest that the Milankovich cycles have acted as a strong linear driver for the surface temperature at Vostok for a much longer time period than the time period over which we can detect their presence by boreholc-temperature measurements. The dating technique developed here can be used in the future in combination with other methods (glaciological modeling, stratigraphic correlations, etc.) to ascertain the chronology of the deeper ice core.

\section{ACKNOWLEDGEMENTS}

The authors thank Yu. Rydvan for providing the field data and appreciate very much the useful and stimulating discussions with C. Ritz, P. Duval, T. Hondoh, J. R. Petit, N. I. Barkov, J. Jouzel, C. Lorius, D. Raynaud and E. Waddington. We should also like to express our special gratitude to the reviewers of this paper for their deep understanding and extremely helpful comments which were rcadily taken into account during the preparation of the final version of our manuscript. This work was supported by the Russian Ministries of Science and of Higher Education. 


\section{REFERENCES}

Barkov, N. I., K. V. Blinov, V. N. Petrov and A. N. Salamatin. 1989. Chislennyyc eksperimenty po rekonstruktsii paleoklimata na osnove rezul'tatov termometrii glubokoy skvazhiny na Stantsii Vostok $v$ Antarktide [Numerical experiments on paleoclimatc rcconstructions from temperature measurements in the deep borehole drilled in the ice shect at Vostok Station, Antarctica]. Mater. Glyatsiol. Issled. 67, $116 \cdot 121$.

Budd, W. 1969. The dynamics of ice masses. ANARE Sci. Rep. 108.

Dahl-Jrnsen, D. and S.J. Johnsen. 1986. Palaeotemperatures still exist in the Greenland ice sheet. Natwe, 320/6059, 250-252.

Genthon, $\mathrm{C}$. and 7 others. 1987. Vostuk ice core: climatic response to $\mathrm{CO}_{2}$ and orbital forcing changes over the last climatic cycle. Tatue, $329(6$ I 38$), 414-418$

Imbrie, J. and J.Z. Imbrie. 1980. Modeling the climatic response to orbital variations. Science, 207 (4434, 943-953.

Jouzel, J. and 6 ohers. 1987. Vostok ice core: a continuous isotope tempcrature record over the last climatic cycle $(160,000$ years). Vatme, 329 6138), 403-408.

Jouzel, J. and 16 others. 1993. Extending the Vostok ice-core record of palaeoclimats: to the penultimate glacial period. Nature, $364(6436)$, $407-412$.

Kapitsa, 1.P. and O.G. Sorokhtin. 1965. Izmereniya tolshchiny lednikovogo pokrova $y$ pokhode po marshrutu Vostok Molodezhnaya [Icc-sheet thickness measurements on the traverse routc from Vostok to Molodezhnaya]. Inf. Byull. Sor. Antarkt. Fiksped. 51, 19-22.

Lliboutry, L. 1981. A critical review of analytical approximate solutions for steady state velocities and temperatures in cold ice-sheets. $z$. Ciletscherkd. Glazialgeol., 15/2, 1979, 135-148.

Lorius, $\mathrm{C}$. and 6 others, 1985 . A 150,000 year climatic recond from Antarctic icc. Nature. 316 6029$), 591596$

MacAveal, D. R., J. Firestone and F., Waddington. 1991. Palcothermometry by control methods. f. Glaciol., 37/127), 326-338.

Martinson. D. G.. N. G. Pisias, J. D. Hays, J. Imbri, T. C. Moore, Jr and N.J. Slackleton. 1987. Age dating and the orbital theory of the ice ages: devclopment of a high-resolution 0 to 300,000-vear chronostratigraphy. Quat. Res., 27(1), 1-29.

Muraver, Ya.D. and A.N. Salamatin. 1990. Mass balance and thermal regime of a cratcr glacicr at Lishkovisiy volcano. Volcanology and Seismologi, 11 3 ), 411-424

Palacogongraphy, Palaeoclimatology. Palaeoecology. 1992. Climatic change inferred from underground temperatures. Palaeogeogr.,
Palaeoclimatol, Palaeocol. (Global and Planetary (hange Section), 98 2/4).

Petit. J. R., L. Mounier, J. Jouzel, Ye.S. Korotkerich. V. I. Kotlyakor and C. Lorius. 1990. Palacoclimatological and chronological implications of the Vostok core dust record. Satme, 343 6253$), 56-58$.

Ritz, C. 1987. Time dependent boundary conditions for calculation of temperature fields in ice sheets. International Association of Hydrological Sciences Publication 170 Symposium at Vancouver 1987 The Phrsical Basis of tee Shert Modelling): 207-216

Ritz, C. 1989. Interpretation of the temperature profile measured at Vostok, East Antarctica. Ann. Glncinl., 12, 138-144.

Rity, C. 1992. Ln modèle thermo-mécanique d'évolution pour le bassin glaciaire Antarctique Vostok-glacier Byrd: sensibilité aux valeurs des paramètres mal connus. Thèse de Doctorat d'Etat. Lniversitó Joseph Fouricr-Grenoble 1.)

Robin, G. de Q. 1977. Ice cores and climatic change. Philos. Trans. R. Soc. London, Ser. B. 280, 143-168.

Salamatin, A. N. 1991. Ice sheet modrlling taking account of glacier icc compressibility. International Association of Hydrological Sciences Publication 208 Symposium at St. Petersburg 1990 Glaciers-OceanAtmosphere Interactions; , 183-192.

Salamatin. A. N., V. Ya. Lipenkov, K. Yc. Smirnov and Yu. V. Zhilova. 1985. Plotnost' lednikovogo l'da i yego reologicheskiye sroystra [The density of glacier ice and its rheological properties]. Antarktika. Doklady Komissii 24, 94106.

Salamatin, A. N., V. Ya, Lipenkoy and K. V. Blinos. In press. Reconstruction of temperature climatic variations on the Antarctic ice sheet surface in the past from temperature measurements in deep borc-holc at Vostok Station. International Associntion of Hydrological Sciences Publicalion Symposium at Tashkent 1993 -- Seasonal and Longterm Fluctuations of Wival and Glaciat Processes in Mountains at Different Scales of Analysis).

Shumskii, P. A. 1969. Dinamicheskaya glyatsiologiva [Dynamic glaciology. Itogi Nauki. Seriya Geografora. Gidrologiva Sushi. Gluatsologina. 1968.

Vostretsov, R. V., D. N. Dmitriyer. O.F. Putikos; K. Y. Blinoy and S. V. Mitin. 1984. Osnovnyye rezul'taty geofizicheskikh issledoraniy glubokikh skvazhhin i ledyanogo kerna $\vee$ Vostochnoy Antarktide ['The main results of geophysical studies of decp horeholes and the ice core in East Antarctica.. Mater. Glvatsiol. Issled. 51. 172-178.

The accuracy of references in the text and in this list is the responsibitity of the authors, 10 whom queries should be addressed. 